\title{
OBREGÓN Y VILLA EN EL ESPEJO AUTOBIOGRÁFICO
}

\author{
OBREGÓN AND VILLA \\ IN THE AUTOBIOGRAPHICAL MIRROR
}

\author{
Luz América Viveros Anaya \\ El Colegio de México \\ lviveros@colmex.mx \\ orcid: 0000-0003-0787-2445
}

RESUMEN: En el presente artículo se comparan las estrategias de composición discursiva y publicación de dos textos pertenecientes al espacio autobiográfico: Ocho mil kilómetros en campaña (1917), de Álvaro Obregón, y la entrevista que hizo Regino Hernández Llergo a Pancho Villa en 1922, publicada en El Universal. La lectura veritativa de ambos textos tuvo consecuencias: en el primer caso, su composición edificada con partes de guerra, cartas, telegramas y narración memorialística sirvió para validar una versión de los hechos asumida por la Historia durante décadas; en el segundo, el reportaje sobre el caudillo se ha visto como causa de su asesinato.

Palabras clave: géneros autobiográficos; Álvaro Obregón; Pancho

Villa; Revolución Mexicana; autofiguración.

ABstract: This paper aims to compare the discursive and publishing strategies of two works pertaining to the "autobiographical sphere": Alvaro Obregón's Ocho mil kilómetros en campaña (1917) and Regino Hernández Llergo's interview with Pancho Villa in 1922, which appeared in El Universal. The factual "veritative" reading of both texts has undoubtedly had consequences in Mexican history. Obregon's piece, based on war reports, letters, telegrams, first-hand accounts and so on, was used throughout decades to validate one side of the story. Likewise, the interview with Villa has come to be seen as the cause of his assassination.

Keywords: autobiographic genres; Álvaro Obregón; Pancho Villa;

Mexican Revolution; autofiguration.

Recepción: 5 de septiembre de 2018; aceptación: 27 de julio de 2020.

D.R. (C) 2021. Nueva Revista de Filología Hispánica Licencia Creative Commons Attribution-NonCommercial (CC BY-NC) 4.0 International 
Al publicar en 1917 Ocho mil kilómetros en campaña, Álvaro Obregón se insertaba en la hasta entonces no muy nutrida tradición de militares y políticos mexicanos que dieron a las prensas la versión de su propia actuación en alguna etapa relevante de la historia militar, política o económica.

Persiguiendo objetivos claramente justificativos o reivindicativos, el gesto del general sonorense resultó de una modernidad discursiva que difícilmente podemos escamotearle. El auge de los textos autobiográficos estaba apenas por verse, lo cual ocurrió en la prensa periódica, de forma clara, hacia la década de 1930, cuando las evocaciones de episodios militares darían tema a gran cantidad de textos durante dos o tres decenios. Tanto fue así que, incluso en el campo más definidamente como literario, testimonios, memorias, retratos y narraciones escritas con intención autofigurativa fueron incluidos por la crítica en el equívoco conglomerado de "Novela de la Revolución", suma de piezas ficcionales o no, en que lo notable es la cantidad de textos narrados en primera persona desde un punto de vista testimonial ${ }^{1}$.

No muchos años atrás, en las vísperas del siglo xx, el espacio de lo autobiográfico había comenzado a abrirse camino como posibilidad de escritura literaria. Aclaro que no considero que el texto de Obregón haya sido escrito con intención literaria, ni que sea eminentemente autofigurativo, pero resulta evidente que el recorrido vital del caudillo militar hace uso de artificios verbales y estrategias narrativas de manera efectiva, y consigue la construcción de una imagen de sí mismo con resultados cercanos a lo heroico. Obregón mismo propone las coordenadas de lectura que rigieron su recepción historiográfica durante muchas décadas: "Este libro está escrito fuera de toda jurisdicción literaria; en cambio, la verdad controla cada uno de sus capítulos" (1960, p. 3).

Edificado como un texto que se basa en partes de guerra, documentos, fotografías, cartas, telegramas y en la escueta exposición de tácticas e impresiones personales, la narración de las batallas de 1915 tiene varias lecturas posibles; la que Obregón mismo propone cuando asegura: "he querido consignar los hechos de índole puramente militar" $(i d$.$) , que juzga las accio-$ nes militares descritas -como hicieron, a la postre, Francisco

1 El uso de este término más como concepto histórico que como género literario es señalado en Olea Franco 2012. 
L. Urquizo y Francisco J. Grajales para la reedición del libro, en 1959-, pero también puede tener una lectura que se centre en las estrategias autofigurativas del narrador, visión que no debe perder de vista su escritura y publicación todavía en el marco de la "guerra de facciones" declarada en 1915.

Catherine Aristizábal (2012) ha estudiado que en el ámbito hispanoamericano - a diferencia del europeo- un motor de la escritura autobiográfica, en el siglo xix, fue su "utilidad... en el espacio público" (p. 45), lo cual dio como resultado unos textos menos atentos a la emoción, los sentimientos y el cuerpo, y más enfocados en conseguir una visibilidad política cercana a la propaganda ${ }^{2}$. Bajo la premisa de la utilidad, Aristizábal pregunta: "¿Hasta qué punto aumentan los escritos personales en periodos electorales?” ( $i d$.$) . Más allá de constatar el peso$ de esa circunstancia, sí se advierte necesario tener en cuenta el momento -en su vida personal y en el entorno político- en que el autobiógrafo decide hacer públicos sus escritos autorreferenciales.

Si en textos tan expositivos como el parte oficial de la Batalla de Celaya que dirigió a Carranza el 10 de abril de 1915, Obregón (1917, pp. 454-462) encuentra oportunidad para configurarse como líder, estratega y héroe, Ocho mil kilómetros en campaña resultó un espacio dilatado para la operación autofigurativa, en que muestra sus inicios, sus andanzas militares y sus triunfos. Esta pretensión se mantuvo incluso post mortem, cuando en 1959 el libro se reeditó como parte de una colección dedicada al estudio del movimiento revolucionario, en el que se añade un prólogo de Francisco L. Urquizo, quien reitera la eficacia, inteligencia y genialidad de Obregón (Garciadiego 2004, pp. xvii-xxxi).

Pedro Salmerón (2009, pp. 1305-1368) ha expuesto ampliamente cómo la historiografía inmediata y buena parte de la mediata construyeron la idea de que la Revolución Mexicana se decidió en los campos del Bajío, basándose primordialmente en los textos de Obregón y de Juan Barragán, Historia del ejército y la revolución constitucionalista; critica tanto la visión obediente a los criterios clausewitzianos, de la guerra resuelta mediante batallas

${ }^{2}$ Aristizábal se refiere específicamente a los textos autofigurativos de Francisco I. Madero, anteriores a su lanzamiento político, y de Domingo Faustino Sarmiento, quien escribe dos textos, uno al inicio de su carrera política y otro en las vísperas de su candidatura, notablemente distintos en su autorrepresentación. Véase AristizÁbal 2012, pp. 43-45. 
decisivas $^{3}$, como el manejo de fuentes que privilegió las constitucionalistas en detrimento de documentos y voces villistas o zapatistas. Ambos componentes fueron determinantes para que la versión canónica hiciera de las batallas de Celaya el episodio que sintetizaba, en el plano simbólico, la lucha entre dos facciones irreconciliables y el desenlace a favor de una de ellas.

¿Qué papel desempeñó, en la operación historiográfica, la fuerza del texto presentado por Obregón? Hoy puede parecer inocente, pero la potencia del testimonio y la exhibición de documentos originales -combinados-se constituyeron en pruebas del conocimiento directo de lo afirmado por los protagonistas, que en este caso eran, además, del bando vencedor. Y más aún, el texto de Obregón fue estimado en la posteridad por haberse publicado en 1917, "en días que estaban muy cercanos los hechos que dieron material al relato del Caudillo de Sonora; y cuando vivía la mayoría de las personas que se citaban en el curso de la obra" ("Nota preliminar", en Obregón 1960, p. vii).

Dichas contiendas celayenses, transformadas en episodio fundamental en la autofiguración de Obregón, le permitieron representar su liderazgo, personalidad y decisiones como definitorias ante la pretendida igualdad de condiciones de los ejércitos. Como ha mostrado Salmerón (2009, pp. 1330-1337), la enmarcación de las personalidades de los caudillos fue repetida y amplificada por buena parte de los historiadores que, en términos generales, señalaron la visión política, panorámica y de alcances nacionales del bando constitucionalista frente a la perspectiva campesina, localista y apegada a la tierra de los convencionistas. La efectividad de la estrategia responde a -y delata- una concepción de la historia que hace descansar la mayor parte de la responsabilidad del triunfo en la capacidad del líder.

Muchas décadas después, la lectura militar de Urquizo cree necesario insistir en la importancia de las personalidades militares de Villa y Obregón como decisivas en el resultado:

3 SAlmerón argumenta que hacia 1915 las ideas de Clausewitz eran paradigmáticas para la historia militar; éstas consistían en concebir "la guerra total como única forma de guerra aceptable en la época moderna...; de la batalla «como única actividad realmente bélica» a la que debe supeditarse todo lo demás; de la destrucción del enemigo como objetivo verdadero de la guerra sólo alcanzable mediante las grandes batallas, y otras ideas cuya adopción por los estadistas europeos fueron de efectos devastadores" (p. 1363). 
[Obregón,] a diferencia de las operaciones que había realizado anteriormente..., asumió una actitud defensiva en contra de tropas que no eran profesionales sino hechas como las que él comandaba, al calor de la Revolución y más o menos con la misma experiencia que las suyas, con la diferencia de que las tropas de Villa gozaban de una superioridad manifiesta tanto en hombres como en armamento, equipo y municiones, lo que consecuentemente las hacía disfrutar de una moral muy elevada; dicho esto sin subestimar la calidad de las tropas constitucionalistas que tenían plena confianza en sus jefes y en su propio poder combativo; sin embargo, en donde realmente existía una diferencia muy marcada era en el alto mando de los beligerantes, pues mientras Villa sólo buscaba el aniquilamiento del adversario por cualquier medio, sin tomar en cuenta los estragos que el fuego enemigo podía causar en sus filas -razón por la que lanzaba sus impresionantes cargas de caballería en oleadas sucesivas-, el general Obregón, calculador, sereno, inteligente y audaz, valiente y agresivo, pero con un sentido humano de la realidad y considerando que el valor no significa la inútil exposición de la vida, primero estudiaba detalladamente la situación para compenetrarse de la misión a cumplir, para conocer al enemigo por batir, el terreno en que se llevarían a cabo las operaciones y, finalmente, para comprobar los medios de que disponía y poder conjugar atinadamente los esfuerzos de estos a fin de llegar a resultados favorables, sin sacrificios estériles por parte de las tropas a su mando (Urquizo 1960, pp. xxv-xxvi; cursivas mías).

Al elegir publicar el devenir de sus campañas en formato de libro, dirigido por tanto a un público muy específico, e ilustrado con fotografías que, en su mayor parte, eran de Jesús $\mathrm{H}$. Abitia -fotógrafo de cabecera del constitucionalismo y amigo de infancia de Obregón-, se conforma una materialidad que impide abstraer sólo el texto verbal, pues implica un tejido discursivo también visual. No obstante, la edición de 1917 ofrece un texto muy distinto del de 1959, pues sólo comparten el discurso verbal; las fotografías de ambas versiones son distintas en selección, número e incluso en función, pues, aunque ambas ilustran, lo hacen desde paradigmas diferentes. La edición de 1917, estampada en la Librería de la Vda. de Ch. Bouret, sólo tiene un breve proemio del autor, y las fotografías se limitan a ilustrar y esclarecer con pies de foto fechas, nombres, localizaciones, contextos; más que una función estética, complementan una función informativa. La edición de 1959, a cargo del 
Fondo de Cultura Económica, Colección Fuentes para la Historia de la Revolución Mexicana ${ }^{4}$, incorpora los estudios preliminares de Francisco L. Urquizo y Francisco J. Grajales -militares de carrera con una visión parcial a favor de Obregón-y un apéndice de Manuel González Ramírez, director de la investigación. El libro conserva algunas de las primigenias fotografías y agrega otras provenientes del archivo de Jesús $\mathrm{H}$. Abitia, además de abundantes croquis que explican gráficamente los escenarios de las batallas y los movimientos de las tropas, imágenes que colaboran todavía más en la construcción de Obregón como gran estratega militar. Con todo, el número de fotografías es mucho menor que en la versión original, y no aparecen inmersas en el texto en una diagramación que entrevere los discursos verbal e icónico, sino que están agrupadas a ambos lados de las hojas en papel couché insertas a lo largo del libro, por lo que quedan sólo relativamente cerca del texto que ilustran, y ese simple cambio de lugar es ya otra narrativa, no se diga la selección misma de las imágenes ${ }^{5}$.

Entre los receptores de la segunda edición, destaca José Emilio Pacheco, quien le dedica el artículo de su columna mensual en México en la Cultura. Luego de ofrecer un relato ameno de las circunstancias históricas de la Revolución en las primeras décadas del siglo xx, señala con sinceridad que las "únicas virtudes literarias" del libro "son la mesura y cierta corrección gramatical", pues la lectura está dificultada "por la inclusión textual de partes y documentos que verifican lo narrado". Sin embargo, afirma convencido que "de todos los generales revolucionarios, Álvaro Obregón fue el único que dejó escrito un testimonio de sus campañas militares" (1959, p. 4), premisa que otorga trascendencia histórica al libro de reciente edición. La "comunidad de interpretación” de 1917 y 1959 es distinta, como lo es la

${ }^{4}$ Es el quinto volumen de la Colección, compuesta hasta entonces por I. Planes políticos y otros documentos (532 pp., ilustrado); II. La caricatura política (700 pp., ilustrado); III. La huelga de Cananea (224 pp., ilustrado); IV. Manifiestos políticos (752 pp., ilustrado); V. Álvaro Obregón, Ocho mil kilómetros en campaña (748 pp., ilustrado).

${ }^{5}$ Ese mismo año en que se reeditó el libro de Obregón, Jesús H. Abitia GARCÉs había narrado unas "Memorias de un fotógrafo constitucionalista" en El Universal ("Revista de la Semana”, 22 de febrero de 1959, p. 1), por lo que es evidente que su archivo se encontraba disponible y que de ahí obtuvieron el novedoso material para la edición del Fondo de Cultura Económica. No obstante, en 1947, mientras se clasificaba el material, un incendio había destruido la mayoría de las fotografías. 
materialidad textual que recibieron, por lo que la condición, clasificación y percepción de la obra cambió también por las variaciones de su forma material (Chartier 2015, p. 26).

Uno de los momentos más delicados y personales del libro es aquel en que Obregón relata cómo perdió el brazo, suceso ocurrido en el marco de las batallas de Celaya que, como he dicho, se ha configurado como crucial en el devenir de la guerra de facciones. La estrategia narrativa que emplea en esa sección es la descripción minuciosa, día por día, de los movimientos de sus tropas y de las del enemigo, elaborada desde una perspectiva panorámica. La hacienda Santa Ana es ponderada en varias ocasiones como una "posición que domina perfectamente el valle", con lo cual estaban "en condiciones ventajosas para iniciar desde allí la ofensiva” (Obregón 1917, p. 560). Aunque los generales Francisco Murguía, Cesáreo Castro y Manuel Diéguez ya deseaban emprenderla, Benjamín Hill y Álvaro Obregón se inclinaban por la defensiva, y a ese plan terminaron plegándose todos para seguir la táctica de "agotar lo más posible al enemigo en sus continuos ataques" y "tomar la ofensiva cuando se tuviera la seguridad de un éxito completo", según argumenta Obregón (p. 554). El ataque estaba previsto para el día siguiente, 4 de junio, y lo terminaban de planear la mañana del 3, en el torreón de la hacienda, cuando desde ahí divisaron que se aproximaba una columna que, a poco, identificaron como la artillería que los villistas hacían avanzar precipitadamente rumbo a la hacienda.

La escena de la mutilación se configura narrativamente como una caída del héroe, una operación de descenso que comenzó en el torreón hasta pocos metros antes de llegar a la trinchera, donde fue alcanzado por una granada. Pese a referirse a acciones veloces, la narración se ralentiza al señalarse continuamente, por un lado, las distancias que el enemigo iba avanzando, el cual también ya emplazaba sus cañones, y por otro, los metros que faltaban al narrador para llegar a la trinchera. Como único rasgo textual de lo emotivo, el relato abandona el plural y se concentra en la primera persona:

Faltaban unos veinticinco metros para llegar a las trincheras, cuando, en los momentos en que atravesábamos un pequeño patio situado entre ellas y el casco de la hacienda, sentimos entre nosotros la súbita explosión de una granada, que a todos nos derribó por tierra. Antes de darme exacta cuenta de lo ocurrido, 
me incorporé, y entonces pude ver que me faltaba el brazo derecho, y sentía dolores agudísimos en el costado, lo que me hacía suponerlo desgarrado también por la metralla. El desangramiento era tan abundante, que tuve desde luego la seguridad de que prolongar aquella situación en lo que a mí se refería era completamente inútil, y con ello sólo conseguiría una agonía prolongada y angustiosa, dando a mis compañeros un espectáculo doloroso. Impulsado por tales consideraciones, tomé con la mano que me quedaba la pequeña pistola "Savage" que llevaba al cinto, y la disparé sobre mi sien izquierda, pretendiendo consumar la obra que la metralla no había terminado; pero mi propósito se frustró, debido a que el arma no tenía tiro en la recámara (pp. 565-566).

La mutilación del cuerpo del narrador suspende la relatoría de la batalla para centrarse en los detalles de la atención al herido. El narrador, que tiene la función de testigo, está literalmente fuera de combate. El desplazamiento por su propio pie a la casa de la hacienda, los muchos discursos de despedida, las últimas disposiciones del caudillo y su traslado en camilla por varios kilómetros continúan durante una página más, hasta que aparece en escena el doctor Osornio, quien le da a beber un anestésico que confunde sus ideas y lo duerme. La narración del combate reanuda con un "mientras tanto", que regresa el relato a la hacienda de Santa Ana con datos escuetos, y supliendo la visión ocular directa que había predominado, están las transcripciones de los partes oficiales que refuerzan su función de documentos independientes -pero armónicos, complementarios y validadores- del discurso narrativo de Obregón.

Las tres fotografías que en 1917 ilustran la narración en páginas sucesivas -imágenes de la Hacienda de Santa Ana del Conde, del traslado en camilla y del general recién operado, con los doctores Osornio y Castro; esta última, muy famosa, muestra el torso desnudo de Obregón, aún en cama, con su brazo mutilado y el rostro cubierto a medias- complementan la percepción documental y realista del discurso testimonial -función que adquirió la fotografía de prensa en las últimas décadas del siglo XIx (Castillo 2007, p. 194)-y, paradójicamente, contribuyeron a la construcción del mito en torno a ese episodio. W.J.T. Mitchell (2009, p. 247) no desdeña el uso ingenuo y supersticioso de la imagen fotográfica en su intercambio libre y fluido con el lenguaje verbal; es más, lo considera un elemento constituyente que hace reliquias de ciertas fotografías. La imagen de Obregón 
en cama, recién mutilado, fue excluida en la edición de 1959 y, en cambio, se añadió una imagen -inexistente en 1917-, a lo largo y ancho de la página, en traje de etiqueta portando la banda presidencial, si bien se aprecia la manga doblada.

El cuerpo -ese aquíabsoluto- como punto de referencia del ahi, próximo o lejano, alto o bajo -observa Paul Ricoeur-, articula la tipología corporal "que va acompañada de algunas valoraciones éticas, al menos implícitas" (2003, p. 195) en el relato que calificará la altura o la distancia. La memoria íntima tejida a la memoria compartida -tal como ocurre en el collage discursivo de Ocho mil kilómetros en campaña-conecta el espacio corporal con el del entorno, y como "de la memoria compartida se pasa gradualmente a la memoria colectiva y a sus conmemoraciones vinculadas a lugares consagrados por la tradición... [surge] la noción de lugar de la memoria" (p. 194). En la arquitectura historiográfica, las Batallas de Celaya son el lugar donde se congregan memorias -íntimas, compartidas, colectivas- a las que Obregón ofrenda, discursivamente, un brazo -si bien la materialidad conservada en formol señalará años después otro lugar de la memoria, también relacionada con su cuerpo: La Bombilla.

El caudillo -al menos el autofigurado en su texto- ha caído, ha perdido parte de su cuerpo, pero, a diferencia de los muchos aludidos en Ocho mil kilómetros como rescatados del campo de batalla ya sin vida, él alcanzó a dictar su legado, según quiere recordar en su texto: "Diga usted al Primer Jefe que he caído cumpliendo con mi deber, y que muero bendiciendo la Revolución" (Obregón 1917, p. 566). Ave fénix, el caudillo se levanta mutilado, pero por ello, más íntegro. La autobiografía consuma la obra que inició la metralla: el abatimiento corporal que, paradójicamente, lo recompone y lo eleva, a tal grado que alcanzará la silla más alta del país de manera legal y no como en la célebre fotografía del decano de los reporteros gráficos mexicanos, Manuel Ramos -reproducida en Ocho mil kilómetros-, con Francisco Villa sentado en la silla presidencial, de la que opinó José de la Colina: "Rara vez una fotografía habrá obtenido tan paralela fijación de la historia y de la mitología" (apud Mraz 2010, p. 233), y que Paco Ignacio Taibo ha relacionado con la imagen del presidencialismo: "De esa silla surge el referente que nos ha de acompañar a los mexicanos los siguientes cien años: la idea de que se combate por la silla, la imagen de la silla como centro del país, como cúpula de la pirámide, como centro del poder" (apud Mraz 2010, pp. 233-234). 
Dos años después de la aparición de Ocho mil kilómetros en campaña, José María Maytorena -uno de los agraviados por el memorialista- ${ }^{6}$ publica desde su exilio en Los Ángeles -apoyado por Rafael Buelna, a decir de José C. Valadés- Algunas verdades sobre el general Álvaro Obregón, texto en el que pretende desmentir las aseveraciones de su paisano sonorense, desenmascarar sus intenciones e-idealmente- frustrar sus ambiciones políticas.

Transcribo en extenso este proemio a su refutación, que además resulta ilustrativo de la percepción que se tenía, hacia 1919, de la función de los testimonios políticos, del valor de las rectificaciones históricas y del espacio convencionalmente veritativo en que se leyeron tales autofiguraciones. Dice Maytorena:

Estando ya para imprimirse [esta] refutación... tuve conocimiento de los rumores que [Obregón] esparció relativos a que pensaba separarse de las actividades políticas de una manera definitiva, emigrando a un lejano país, en expatriación temporal, como demostración suprema de su desinterés... Conocedor como lo soy, del verdadero carácter de mi gratuito enemigo, de la insaciable ambición que lo devora, de su incurable fatuidad, y de sus tendencias a la farsa cómico-trágica, determiné reservar mi trabajo, seguro de que se me presentaría una oportunidad favorable para darlo a luz, en la cual, a la vez que cumpliría con el deber de hacer rectificaciones históricas trascendentales y volvería sobre los fueros de la verdad ultrajada, prestaría un buen servicio a mi país, dándole algunas claras ideas sobre una personalidad aparatosa y vana, falsa y tornadiza, sin escrúpulos y peligrosa, que podría, en un momento dado, aprovechar hábilmente las circunstancias para exhibirse y recomendarse como el hombre necesario y el instrumento único de salvación nacional. Y no me equivoqué en mis conjeturas. Ni hubo tal emigración a tierras lejanas, ni tal apartamiento de las actividades políticas. Obregón simplemente simuló esas actitudes para hacer interesante su personalidad, por pura pose, para atrapar incautos que, fascinados por el brillo de acciones desusadas -Obregón pensó-, en reacción admirativa

${ }^{6}$ En su libro, Obregón transcribe una hoja que redactó al instalarse en México el gobierno de la Convención, y que circulaba profusamente en Veracruz bajo el título de "Cargos concretos contra Francisco Villa, José María Maytorena y Felipe Ángeles”, donde lo acusa de haber apoyado a Huerta y de no haber aceptado que Obregón, Talamante, Carpio y Roberto Cruz lucharan contra él, de haber huido al extranjero durante seis meses, de suprimir las elecciones y de reunir fondos de manera fraudulenta, entre otros cargos. Véase “Contra José María Maytorena”, en ObRegón 1917, pp. 356-358. 
acudieran solícitos a sacarlo de su clausura y a levantarlo sobre $e l$ pavés de su devoción (1919, p. 3).

En la nota preliminar a la reedición de Ocho mil kilómetros, el Patronato de la Historia de Sonora -encarnado, como sugiere Salmerón (2009, p. 1308), en Manuel González Ramírez, por encargo de Aarón Sáenz y Abelardo Rodríguez- afirma que el libro de Obregón "no fue motivo de rectificaciones por ninguno de los aludidos, y menos aún obligado a modificarse en cuanto a su contenido", "salvo por lo escrito por don José María Maytorena", el cual publicó "un folleto" en que "se limitó a expresar desahogos personales, enderezados contra el general Obregón como supervivencia de la lucha de facciones que había llevado a Obregón y a Maytorena a militar en bandos contrapuestos". Y ahí se interpreta que Maytorena "se esmeró en negar las aptitudes personales, militares y políticas del general Obregón" (Obregón 1960, p. vii), rasgo que, incluso visto desde décadas después, me parece revelador del propósito inmediato que tuvo no el "folleto" de Maytorena, sino el libro del Caudillo: enaltecer dichas aptitudes personales, militares y políticas.

Si bien pretendo subrayar que el propósito apremiante del Caudillo fue la autofiguración heroica, pactando con su lector un contrato autobiográfico de discurso veraz en el proemio, también implicó en ese mismo acto la acuñación de la versión del vencedor; moneda de buena ley a juzgar por su valor de cambio duradero. La percepción de su autofiguración todavía alcanzó a devaluarse al paso de los años: su visión política se transmutó en "politiquerías"; ; perduraron más las virtudes de sus estrategias discursivas como insumos historiográficos al ser admitido, a un mismo tiempo, según demuestra Salmerón en su artículo, como testigo de la historia, como historiador de primera mano y como la fuente misma ${ }^{8}$.

${ }^{7}$ Como aparece en la explicación que da Alan Knight en su revisión del tema: "Villa derrochaba hombres y dinero, Carranza y Obregón proyectaban, se preparaban, politiqueaban: ésa era la manera de ser de cada uno" ( $L a$ Revolución Mexicana, t. 2, apud SALMERón 2009, p. 1343).

${ }^{8}$ El redactor de la nota preliminar de Ocho mil kilómetros se permite afirmar que Obregón "se anticipó a los futuros arribistas e improvisados historiadores, pues dijo el general Obregón que escribió Ocho mil kilómetros en campaña porque era el poseedor de los documentos originales que constituían pruebas de lo por él afirmado; y porque el conocimiento directo que tuvo de la campaña lo colocaban en mejores condiciones de apreciar y de 
En el ir y venir de testimonios sobre los hechos, y el estira y afloja para establecer verdades o para refutarlas y recomponer los fueros de la "verdad ultrajada", fenómeno que ocurrió a partir de la década de 1920 y con notable incremento en las de 1930 y 1940, Obregón había dado un golpe definitivo por lo temprano de su texto autovindicativo: supo conjugar el verbo madrugar. La figura de Maytorena, en cambio, se transparentó durante décadas a partir del triunfo de la facción sonorense, y con él, su texto, a pesar de quienes pudieran compartir su opinión; por ejemplo, Federico Gamboa asentó en su Diario, en noviembre de 1922: "Deduzco de la lectura de ese folleto [de Maytorena] que no estaba yo muy equivocado sobre la opinión que tenía yo sobre Obregón. Aún pudiera tachárseme de benevolente y de que me quedé corto" (1996, p. 92).

Muy tempranamente, los textos de Obregón y Maytorena trenzaban la discusión en la operación hermenéutica sobre los hechos del pasado reciente. Elizabeth Gómez Rodríguez investiga actualmente el auge del espacio autobiográfico en la prensa nacional durante esas décadas, y entre sus conclusiones destaca la aparición de nuevos sujetos autobiográficos -religiosos, celebridades del espectáculo y "gente común", como la llaman en la prensa- que publicaron memorias, autobiografías y testimonios de episodios revolucionarios. Pocos de los relatos llegaron a reunirse entre dos pastas $-\mathrm{y}$ el soporte de publicación es, en sí, un tema relevante-, pero es evidente que esas voces influyeron directamente en sus contemporáneos y aún hoy siguen recomponiendo la construcción historiográfica de las distintas etapas de la Revolución.

En un iluminador estudio sobre la representación del pasado desde la fenomenología de la memoria, Paul Ricoeur explica tres fases de la operación historiográfica de la memoria: "del estadio del testimonio y de los archivos, pasa por los usos del porqué en las figuras de la explicación y de la comprensión; y concluye en el plano escriturario de la representación historiadora del pasado" (2003, p. 14).

La escritura testimonial sobre la Revolución Mexicana podría tener como principal disparador, aunque no único, la necesidad de diferentes actores por fijar su postura y su versión de los hechos -traumáticos por lo violentos y sangrientos nato de la Historia de Sonora, "Nota preliminar", en ObRegón 1960, p. viii). 
de algunos episodios- a partir de la fuerza del discurso testimonial-memorialístico. Este discurso, que naturalmente perteneció al ámbito privado e incluso oral, había comenzado a emerger a lo público y a afianzar su prestigio en el terreno literario apenas pocas décadas atrás. Ese surgimiento del yo, autofigurado para validar la perspectiva de testigo que da cuenta de lo que ocurrió alrededor, o la autofiguración que narra la propia vida, debe estudiarse como un cambio muy relevante en el devenir discursivo, que en México, como en el resto de Latinoamérica, tardó en echar raíces en nuestra cultura.

Sin casi antecedentes en la tradición mexicana, el espacio de lo autobiográfico -diarios, memorias, autobiografías- permaneció lejos de la sanción pública con la sola excepción de los relatos de viaje, donde un yo se autofiguraba en tanto fuera pertinente para mostrar el recorrido geográfico del viajero. Sin que podamos considerarlos literarios, pero echando mano de grandes dosis autofigurativas, notables funcionarios escribieron memorias, apuntes o justificaciones de su actuación militar o política, entre quienes sobresalen Agustín de Iturbide, Antonio López de Santa Anna, Ignacio Comonfort, Manuel Payno, Sebastián Lerdo de Tejada, José María Iglesias, Porfirio Díaz. Algunas memorias, escritas por otra persona, requieren un estudio de esa mediación entre la oralidad de lo narrado o dictado y su concreción escritural; otras se han señalado como impostura (memorias apócrifas, como las de Victoriano Huerta). En esa frágil tradición, escasa, es donde mejor podemos adscribir a Álvaro Obregón, quien publicó su libro una vez que el espacio autobiográfico había emergido, cambiado la forma de leer las memorias y formado un público ${ }^{9}$.

El casi vacío del género en las décadas previas lo explica Silvia Molloy (1996) como consecuencia de la falta de un espacio institucional para el género, pues -advierte, inspirada en Philippe Lejeune- "la autobiografía es una manera de leer tanto

9 Sólo hacia finales del siglo xıx, comenzaron a publicarse y a tener un público lector -no como un hecho aislado, sino como una tendenciamemorias, autobiografías y diarios en los que se tornó principal e importante la autofiguración del narrador-autor-personaje principal. En las letras hay ejemplos tan notables como Impresiones y recuerdos (1893), de Federico Gamboa; El libro de mis recuerdos (reunido en volumen en 1905), de Antonio García Cubas; Memorias, reliquias y retratos (1900), de Juan de Dios Peza; y Memorias de mis tiempos (publicado póstumamente, 1906), de Guillermo Prieto, entre otros más. 
como una manera de escribir" (p. 12), por lo que, hasta entonces, lectores y críticos sólo habían dispuesto para esos discursos de los cajones de la historia o de la ficción. La definición de Lejeune es particularmente útil para analizar textos de la primera mitad del siglo xx; concibe la autobiografía como un "relato retrospectivo en prosa que una persona real hace de su propia existencia, poniendo énfasis en su vida individual y, en particular, en la historia de su personalidad" (1994, p. 50), y que, en el caso de las memorias, desplaza el relato a la perspectiva de testigo.

La prensa periódica fue la gran plataforma de publicación donde, en el puente de los siglos XIX-XX, se formó un público y se institucionalizó un género de escritura; los diarios industrializados, en el xx, brindaron cada vez más una relativa democratización de la posibilidad de ofrecer la propia visión de los hechos. Junto a los textos autobiográficos de plumas consagradas como las de José Juan Tablada, Victoriano Salado Álvarez y José Vasconcelos, se publicaron testimonios, memorias y autobiografías de muy diverso tipo. Elizabeth Gómez ha identificado, en un estudio sobre la prensa periódica entre 1920 y 1940, un marcado predominio de individuos relacionados con la res publica como intelectuales -los que más abundan-, políticos y militares. En la década de 1940, el espectro se abre un poco y aparecen relatos de vida de religiosos y de gente común. Observa también cómo inició entonces la consolidación de los géneros autobiográficos, con predominio de la Revolución Mexicana, como materia de rememoración, hasta la década de 1940, en la que comienza a aparecer también el tema de la Segunda Guerra Mundial ${ }^{10}$.

Uno de los episodios más relevantes de ajuste de cuentas y asignación de culpas había ocurrido pocas décadas atrás, en 1887, producto de una entrevista a Mariano Escobedo, publicada en un famoso reportaje con relevantes declaraciones del general a propósito de la supuesta traición a Maximiliano del general conservador Miguel López. Aquella polémica, cuyas consecuencias duraron casi dos décadas -que enfrentó a El Diario del Hogar, El Nacional, El Tiempo, La Voz de México y El Comba$t e$, y que se debatió también en la calle a golpes de bastón entre

10 Gómez, "Prensa y representaciones discursivas autobiográficas en el siglo xx", datos que generosamente me proporcionó de una investigación en curso en el Instituto de Investigaciones Bibliográficas. 
Ángel Pola y Victoriano Agüeros- dio origen a gran cantidad de textos autobiográficos publicados en la prensa, en los que unos y otros intentaban demostrar testimonialmente $-\mathrm{y}$ hasta con una carta, que luego resultó falsa- diversas "verdades" alrededor de la caída del emperador (Viveros 2019, pp. xxxix-1).

Abundantes fueron las memorias, los diarios, relatos de viaje, epistolarios, alrededor del episodio imperial que ofrecen otras voces y texturas de un acontecimiento del que muy prontamente se apropió la historia oficial, codificada en México a través de los siglos-versión liberal del discurso integrador de la nación-, visión de la historia que "perdía la pluralidad de voces y de interpretaciones que habían hecho la riqueza del periodo que se cerraba con su aparición” (Pi-Suñer 2011, p. 30). Como ocurrirá décadas adelante con la Revolución Mexicana, la historia nacional, en la versión de los vencedores, se había convertido "en crónica y justificación del triunfo de un proyecto político e ideológico, legitimando la permanencia exclusiva en el poder de sus promotores" (Pani 2004, p. 24). Erika Pani señala la necesidad de estudiar las relegadas "historias del Imperio" no para reconstruir los hechos tal y como sucedieron entre 1864 y 1867, sino para "desmenuzar sus relatos, más por lo que nos dicen sobre la época y los hombres que los escribieron, que sobre el objeto de que tratan" (p. 27).

En otras tradiciones, la formulación de la narrativa historiográfica se pudo nutrir de abundantes relatos memorialísticos -autobiografías, memorias, diarios, testimonios-; en el caso de la independencia argentina, por ejemplo, los textos de Manuel Belgrano, Cornelio Saavedra, Gervasio Antonio Posadas, Cornelio Zelaya, Juan Cruz Varela, etc., están reunidos en libros que hoy son parte del canon, como la Biblioteca de Mayo. En México no ocurrió así; hasta hace pocas décadas no había un espacio autobiográfico asumido como insumo historiográfico, pero tampoco desde las letras se había atendido mayormente en cuanto a sus virtudes autofigurativas.

Cosío Villegas identifica en las Memorias de Porfirio Díaz un gesto astuto, previsor, que muestra que Díaz y sus colaboradores

tuvieron un fino sentido de la posteridad y de la historia..., pues se dieron cuenta clara, primero, de que la fama oral perece con la lengua y el oído del contemporáneo; y que la escrita, a la inversa, sube de valor con el tiempo; y se dieron cuenta, finalmente, de que si uno no escribe su propia historia, otros la escribirán, y 
todas las probabilidades son en el sentido de que la segunda sea menos placentera que la primera. Las Memorias del general Díaz..., después de cincuenta y siete años de publicadas, en nada importante han sido adicionadas o rectificadas (2004 [1949], p. 111).

Como las de Obregón años más tarde, las Memorias de Porfirio Díaz también enfocaron "sólo las hazañas del héroe pero no las acciones turbias o discutibles del hombre mortal" (pp. 111-112). Aun así, Cosío Villegas niega rotundamente que Díaz las haya escrito "para preparar ninguna reelección sino para la posteridad... para la eternidad, por lo visto" (p. 112).

Las de Obregón, en cambio, me parecen escritas primordialmente para preparar su elección; como efecto secundario, su permanencia como fuente se explica no sólo por las virtudes testimoniales-documentales señaladas, sino por la tardía atención de los historiadores a otro tipo de "historias" y por la fuerza de una versión que era cimiento de la revolución institucionalizada. Pedro Salmerón (2009) sugiere, por ejemplo, los testimonios del general Juan B. Vargas o de Adalberto Calzadíaz Barrera, en cuanto aportan la visión villista menos aprovechada por los historiadores. Este último "es una fuente riquísima para entender las razones y pulsiones de los soldados villistas, así como muchas de sus versiones de los acontecimientos" ( $p$. 1349); es una mirada "muy enriquecedora por el rescate del testimonio directo de un grupo que no había tenido voz", y se subraya el hecho de que ahí aparezca "por escrito una sostenida versión villista: la de las balas de salva o de palo en las batallas de Celaya y Trinidad" (p. 1350).

Me detengo en la importancia que concede Salmerón a la codificación escrita del testimonio oral. Las balas de salva, la falta de parque en Celaya, la cesión del arsenal veracruzano a los constitucionalistas, todo esto permite transformar la explicación canónica de las razones del triunfo sin recurrir al demérito de Villa, que parece consustancial a la elevación heroica de Obregón. El as bajo la manga parece consistir en el prestigio de la escritura y, en este caso además, en una posición enunciativa como la de la autobiografía, que coloniza y canoniza el propio espacio "adelantándose a voces futuras", donde "la inmediatez de «lo vivido» se traduce en una voz que testimonia por algo que sólo ella conoce" (Arfuch 2002, p. 59).

Frente a la concepción de los textos autofigurativos como expresión pura y directa de "la verdad" que Obregón preten- 
de hacer valer -y que hizo valer-, Leonor Arfuch contempla la importancia no tanto del "contenido" del relato -como colección de sucesos, momentos y actitudes-, sino de "las estrategias -ficcionales- de auto-representación" (p. 60). Esta construcción narrativa de una verdad condimentada con vivencias, recuerdos, puntos de mirada, y hasta lo silenciado, se adscriben a la idea de Paul de Man de "la vida como producto de la narración" (apud Arfuch 2002, p. 61), y no al revés.

Sin embargo, hacia la primera década del siglo $\mathrm{xx}$, los textos literarios habían terminado de definir la configuración del espacio autobiográfico como un tipo de lectura y escritura que, más allá de fijar verdades -que era imposible que se conciliaran-, lo que establecía era la posibilidad de un discurso válido -ni totalmente histórico ni aparentemente ficcional-, el cual, en última instancia, exponía la verdad de un sujeto para quien quisiera conocerla, cuya pretensión veritativa consistió en la ambición de representar de verdad el pasado (Ricoeur 2003, p. 303). Sujeto al que se percibió, también, como "documento humano" - a lo Goncourt-, cuya voz por primera vez emergía como resultado de una transformación cultural operada entre nuestros escritores, el público y la tradición.

En ese auge, creado y alentado, en gran parte, por la prensa periódica, ocupó un lugar muy importante la entrevista testimonial, que resguardaba y autentificaba las palabras dichas. Antes de que se utilizaran aparatos de grabación de voz, la taquigrafía recogía textualmente el discurso del entrevistado, quien era también fotografiado en su entorno para presentar ante el público una construcción imagen-texto lo más cercana al diálogo vivo. La moda de la entrevista -introducida en México, tal vez, por Ángel Pola, y practicada en El Diario del Hogar, El Nacional, El Mundo Ilustrado y otras publicaciones de la primera década del siglo xx-permitió que desde la década de 1880 se asaltara la intimidad del entrevistado, quien comúnmente recibía a la curiosa visita en su casa, y ésta era descrita detalladamente como escenario -umbral entre lo público y lo privado que daba contorno a la interioridad-que completaba la autofiguración propia de este espacio autobiográfico construido en el diálogo.

Desde la década de 1920, y por más de dos decenios, la prensa mexicana y, en el sur de Estados Unidos, los periódicos de Ignacio Lozano - La Opinión de Los Ángeles y La Prensa de San Antonio- dedicaron gran espacio a distintos relatos autobiográ- 
ficos sobre episodios revolucionarios. En estos últimos, José C. Valadés incluso configura un género novedoso, que Javier Garciadiego (2007, p. 13) bautizó como "reportajes históricos" de enorme valor, pues rescatan "el testimonio de los parcialmente vencidos", cuyo contenido estaba condenado a no conocerse por razones políticas; materiales que, de hecho, "no han sido [muy] utilizados en la historiografía de la Revolución Mexicana" por ser de difícil acceso incluso para los expertos: "no son inéditos, pero sí virtualmente desconocidos".

El peculiar formato de la entrevista permite concentrar "las funciones, tonalidades y valores -biográficos- reconocibles aquí y allí, en los diversos géneros..., que podrá devenir indistintamente biografía, autobiografía, historia de vida, confesión, diario íntimo, memoria, testimonio" (Arfuch 2002, p. 117). La afirmación del género derivó

de la mostración de la proximidad, de su poder de brindar un "retrato fiel" -en tanto atestiguado por la voz [o, sugiero aquí, por la transcripción de la palabra dicha]- y al mismo tiempo no concluido -como, de alguna manera, el pictórico o la descripción literaria-, sino ofrecido a la deriva de la interacción, a la intuición, a la astucia semiótica de la mirada, a lo sugerido en el aspecto, el gesto, la fisonomía, el ámbito físico, escenográfico, del encuentro (p. 118).

En el espacio dialéctico y abierto a la imbricación genérica de la entrevista, es donde vemos aparecer un personaje que había conquistado gran notoriedad. Si Pedro Salmerón se queja de la construcción historiográfica que minimiza o ningunea las capacidades del Centauro del Norte, el famoso reportaje realizado en 1922 por Hernández Llergo, "Una semana con Francisco Villa en Canutillo", permite observar cómo él mismo intentó, en su discurso autofigurativo, desactivar ese imaginario, al aludir en distintos contextos a sus pretendidas ignorancia y rusticidad, para negarlas inmediatamente, para brillar con más fuerza en su inteligencia innata y en su intuitiva bondad.

Dado el contexto, asombra conceder que con lo publicado en esta entrevista estaba, tal vez, firmando su sentencia de muerte. Cuando se analizan textualmente las razones, Villa aparece en el reportaje como una amenaza ante quienes se disputaban el poder, al enviar un mensaje ambiguo entre una candidez casi infantil y una calculada autofiguración heroica. En una de las 
"platicadas" que sostuvo con el entrevistador, antes de la cena, espetó a los periodistas, sin preámbulos: "Yo, señores, soy un soldado de verdad. Yo puedo movilizar cuarenta mil hombres en cuarenta minutos... Comprendo que éstas son palabras mayores, pero ya lo he demostrado. Yo no soy hombre culto, lo comprendo, pero tengo inteligencia, una inteligencia dotada por la Naturaleza" (Hernández Llergo, 16 de junio de 1922, p. 1). Sin pretender simplificaciones maniqueas, la entrevista confirma por su propio dicho los tópicos que fueron luego, tal vez, tensados hasta la exageración.

Friedrich Katz (1998, pp. 354-357) estudia las implicaciones políticas de esa entrevista, ocurrida pocas semanas después de la carta de Villa a Obregón en torno a las tierras de los Terrazas en Chihuahua -en que aquél triunfó-, y advierte que esa aparente victoria pudo ser la causa original de su muerte, pues Regino Hernández Llergo, reportero de El Universal, acudió tal vez enviado por el gobierno para explorar con otro método las verdaderas opiniones de Villa respecto a asuntos de política actual.

Como señala Katz, Villa proyectó la imagen de un hombre fuertemente interesado en su hacienda; “durante horas, paseó a Hernández Llergo por Canutillo y le describió todos los aspectos de su economía. Durante horas disertó sobre los aspectos técnicos de la producción, le mostró orgullosamente al reportero los gallos de pelea que estaba criando y le hizo conocer la escuela" (p. 355). Pero esa entrevista, señala Katz, "causó consternación en el gobierno y muy especialmente entre Calles y sus partidarios...; dijo claramente que su promesa de no participar en política sólo se refería al gobierno de Obregón, que terminaría en 1924. Dio a entender que, a partir de esa fecha, podría ser candidato a gobernador de Durango" (pp. 355-356).

En efecto, gran parte de la entrevista, desarrollada a lo largo de una semana, está enmarcada textual y visualmente por escenarios que refuerzan la prosperidad de su administración como hacendado; en el contexto global del reportaje, bien puede interpretarse Canutillo como microcosmos de un estado o nación en manos de un hombre rústico y sin ambiciones como Villa: una hacienda autosustentable, la atención puesta en la educación infantil, la gente reconociéndolo como líder, los molinos y tiendas al alcance de la población, y él como cabeza, vigilando que los diferentes sectores de esa patria en escala marcharan armónicamente. Villa repite una y otra vez cómo llevó la hacienda de la ruina a la prosperidad, y cómo él, en 
Canutillo, tiene "resuelto el problema agrario, que tanto quehacer ha dado a los políticos de mi país, y que es tan sencillo resolver bien" (Hernández Llergo, 13 de junio de 1922, p. 1).

El pacto de lectura autobiográfico está suscrito apenas al comenzar la entrevista; para aceptarla, Villa pone como condición "que digan la verdad... yo quiero que ustedes, como jóvenes que son, como gente más culta que yo, como mexicanos, hermanos de mi raza y de mi sangre, digan la verdad... yo quiero que ustedes obren de buena fe" (id.).

La preocupación autofigurativa es clara desde la segunda entrega del reportaje, cuando por primera vez tiene la voz como anfitrión en Canutillo: "Desde hace dos años, las prensas han estado hablando mal de mí, diciendo mentiras, llamándome bandido, engañando al pueblo, a mis hermanos" ( $i d$.$) .$ A pesar de estar neutralizado políticamente por Obregón, tanto el reportero como Villa aluden reiteradamente a la notoriedad política y militar del entrevistado. Esto era inevitable por el aspecto modélico de la vida ejemplarizada que implica el género entrevista (Arfuch 2002, p. 118).

La inmediatez y autenticidad que conlleva lo expresado se torna un arma de doble filo en la configuración de Villa en los momentos de entrevista. Aparece por ratos, indistintamente, impulsivo y contenido; expansivo y retraído, impositivo y negociador. El periodista mismo mantiene presente el miedo como motivo constante en su relato; por ejemplo, cuando el fotógrafo no quería levantarse por la mañana, le dice el narrador-periodista: "-¿Pero qué no te acuerdas que estás en Canutillo? -grité. Y él, al oír semejante exclamación, dio un brinco, se restregó los ojos y comenzó a vestir apresuradamente. ¡De lo que es capaz el miedo!" (Hernández Llergo, 14 de junio de 1922, p. 1).

Villa se esfuerza por mostrarse hábil, capaz, todólogo: "aquí no hay más ingeniero que yo, amigos"; "la misma tenacidad que tuve para la guerra, la tengo ahora para el trabajo; yo soy agricultor, soldado, ingeniero, carpintero, mecánico -añadió contando con sus dedos...-, ¡hasta albañil! Si todos los mexicanos fueran otros Franciscos Villas, otra cosa sería de mi patria y de mi raza" $(i d$.$) ; "yo soy agricultor... isi en mi pueblo, señor,$ hubiera muchos Franciscos Villas, tan amantes de la tierra, mi raza dejaría de sufrir mucho, mucho!" (17 de junio de 1922, p. 1). También se esfuerza por mostrarse interesado en la educación y las letras: lleva a los reporteros a una larga visita a la escuela, que resulta modelo, y les muestra luego su biblioteca, donde 
se hallan El tesoro de la juventud, el Diccionario español Appleton, la Gramática castellana de Rafael Ángel de la Peña, la Geografía de Schultz, La divina comedia, El cocinero moderno, libros de Salgari, la Pedagogía de Rébsamen, el Alma americana, entre otros.

Esa estrategia, ese ego inflamado por la presencia del periodista y el fotógrafo, terminó siendo contraproducente para Villa, pues, como era de esperarse en el género entrevista, ésta construyó un espacio suficientemente íntimo y propicio a lo veritativo, en el cual se recordó la anécdota de cuando tuvo prisionero y dejó libre a Obregón; se preció de haber sido él el primero en señalar como tirano a Venustiano Carranza y, para rematar, ante la pregunta de cuántos hombres tenía en su hacienda, contestó: "-Hay, contando con los ranchos que pertenecen a Canutillo, mil ochocientos hombres, todos armados. / -¿Todos armados? / -Todos. Con armas nuevecitas, y parque suficiente. ¡Ya ve usted, señor, todos están silencitos!” (id.).

En los distintos espacios para el desarrollo de la entrevista que por una semana reunió a los periodistas con el mítico excombatiente, hay alusiones que permiten deducir el enfoque episódico y de hechos singulares o insólitos con que concibió Villa el relato de sus memorias. En las noches que compartieron la cena, contó algunas anécdotas que -a decir de Hernández Llergo- aportaron datos hasta entonces desconocidos. Sin embargo, aunque Villa aseguraba tener escritas sus memorias "día a día", "completitas", pensaba conservarlas hasta su muerte para que sus hijos las entregaran "al más prestigiado historiador mexicano para que las dé a conocer a mi pueblo" (15 de junio de 1922, p. 1), aseveración que delata una concepción de la memoria y su escritura como operaciones independientes, ya que la articulación del recuerdo parece suponer una reescritura textual consagratoria por parte de un historiador.

La descripción escenográfica no escapó a la astucia semiótica de reportero y fotógrafo: en la sala de su casa tenía un busto en bronce, de tamaño natural, del general Felipe Ángeles, "hombre consciente y de buen corazón" $(i d$.), mientras en la biblioteca lucía un retrato de Villa acompañado de otros jefes revolucionarios: "-Éste -me indicó, señalando al que estaba a su derecha- es Rodolfo Fierro, un hombre muy malo... según dicen -terminó, encogiéndose de hombros" (17 de junio de 1922, p. 1). Esa gestualidad es reveladora de una opinión para ser presentada pero no asumida. La asociación de personajes tan disímiles en su entorno, Felipe Ángeles y Rodolfo Fierro, 
que subrayaron con distintos recursos reportero y fotógrafo, reafirmó una percepción del carácter binario de Pancho Villa. La dualidad ángel-demonio, adjudicada por la historiografía inmediata, es sintetizada por Juan Sánchez Azcona en la pieza biográfica que le dedica en 1930, desde su exilio en La Habana: "desde que lo conocí me interesó porque encontré en él algo extraño que hasta entonces no había encontrado en mortal alguno: una inexplicable mezcla de pureza para el bien y de inconsciencia para el mal" (p. 3).

El reportaje fue difundido en quince idiomas, y hay en él un uso muy claro de estrategias sensacionalistas que había promovido Félix F. Palavicini, quien además impulsó la redacción y publicación de reportajes de largo aliento que abundaran en "pasajes que pudieran provocar en el lector sorpresa, miedo, repugnancia, frustración o cualquier emoción que los motivara a comprar el ejemplar del matutino" (Sierra García y Ramírez Vuelvas 2009, p. 17, passim). El reportaje utiliza las técnicas de suspense de la novela folletinesca, la duda como ilación de la historia o el énfasis en los momentos de drama, pero también técnicas narrativas como el diálogo, la prosopografía, la etopeya y el retrato psicológico (p. 23).

Una dimensión fundamental en la comprensión de las estrategias figurativas que hasta aquí se han destacado es el despliegue visual con el que apareció el reportaje a lo largo de siete días, ocupando la primera página de la segunda sección de El Universal. Más de la mitad del espacio superior de la plana periodística tamaño sábana presentó siempre un collage fotográfico que, si bien cumplía una función eminentemente ilustrativa del texto verbal de Regino Hernández Llergo -ubicado en la parte inferior y en páginas interiores-, es un montaje cuya fuerza en la creación de un significado conjunto me parece determinante.

Los reporteros de El Universal continúan en 1922 una deriva del género aclimatado en México, en la década de 1880, por reporteros como Ángel Pola, Manuel Caballero y Gabriel Villanueva (Bonilla 2002 y 2014). En el famosísimo reportaje titulado "15 de mayo de 1867", Ángel Pola, a propósito del vigésimo aniversario de la ocupación de Querétaro -episodio con el que culminó el Segundo Imperio-, se trasladó a la Hacienda de la Laguna, en Chamacuero, Guanajuato, para entrevistar al general Mariano Escobedo, cuyas declaraciones desataron una enardecida disputa periodística. El reportero narra el traslado desde 
la Ciudad de México por el "caballo de vapor" hasta la estación donde ya lo esperaban tres personas que lo llevaron en carruaje; las peripecias de la llegada, de noche, a la población, tras cruzar un río y subir una loma; y finalmente, el arribo a la casa grande y la descripción del encuentro con

la venerable figura del General: alto, flaco, huesoso, vestido con saco de dril ruso hasta las corvas, pantalón burdo de ancha franja desprendida de la costura lateral del mismo casimir, sombrero de palma muy alado, zapatos de suela y tacón fuertes, metidas las manos en las bolsas, color moreno, rostro oval, frente amplia y surcada en distintos sentidos de arrugas impresas por el carácter de su profesión, cejas poco pobladas y ligeramente corvas, ojos de mirada revelando a la vez que la dulzura, la energía, nariz afilada y recta, los surcos naso-labiales marcados por la edad, barba cana, bastante espesa y dividida por el mentón en dos porciones elegantes terminadas en punta, labios delgados y el superior cubierto por un poblado bigote, orejas levantadas de muy amplio pabellón (Pola 1887, p. 1).

En ese momento, el reportero tenía que hacerlo todo con la palabra; ninguna imagen (grabado, dibujo, croquis) acompañó su texto. Pola conversó breves momentos, se fue a dormir y tuvo que levantarse a las cuatro de la mañana, cuando escuchó los pasos del general en el corredor, pues ya se encontraba de pie "meditando en los trabajos de la hacienda". El reportero se valió entonces de profusas descripciones sobre la vida y hazañas de Mariano Escobedo, que durante largos párrafos ofrecen a los lectores un contexto de la relevancia del personaje entrevistado. Sólo después da cuenta del recorrido por la hacienda del general, quien le enseñó los rastrojos, sus cultivos de trigo y cebada, los agostaderos, las represas, los mozos, los ganados y los graneros. De regreso al casco de la hacienda ocurre la trascendental conversación, mientras le muestra sus reliquias y el manuscrito de unas Memorias, "obra a que da la última mano, que transformará en mucho la hoy dicha Historia de México, de las que están concluidas las narraciones desde el año 47 hasta 72" (p. 2). Bajo el subtítulo "La única verdad sobre la toma de Querétaro", el reportaje pone en diálogos la conversación en que Escobedo develará la inocencia del coronel conservador Miguel López, señalado hasta entonces como traidor. En ese formato, aparentemente simple, radica la modernidad del género que activa los resortes de un incipiente sensacionalismo. 
Con una estructura narrativa muy parecida, pero conjugada con las posibilidades de la fotografía, "Una semana con Francisco Villa en Canutillo" es una conspicua muestra del género, que aprovecha las ventajas visuales de las empresas periodísticas de los años veinte y las prácticas lectoras de un público muy formado ya frente al fotorreportaje, para centrar el discurso verbal en la creación de atmósferas. La narración se demora en los signos que manifiesten la irrupción del espacio más cercano al general y la intimidad que les otorga el hospedaje en la recámara de los hijos de Villa, en la finca principal, pues el reportero se concentra en describir detalles reveladores. El collage fotográfico funciona como instancia documental del relato -valor que grandes sectores de la población siguen atribuyendo a las imágenes con una "carga nada desdeñable de ingenuidad" (Castillo 2007, p. 193) - y al mismo tiempo ofrece una narrativa propia manejada con las dimensiones, los recortes, las formas, el acomodo de los elementos, los pies de imagen y la puesta en página.

En las siete entregas, el fotorreportaje tiene el mismo formato: las imágenes fotográficas están recortadas en silueta, en cuadro o redondeadas y enmarcadas con líneas geométricas, superpuestas, con pies de foto elaborados a mano que cumplen una función de ubicación de las personas y los espacios retratados. Se combinan las tomas panorámicas de calles, iglesias, casas, mercados y teatros en Parral y en Canutillo, con tomas en primer plano de Villa, del general Trillo, de los hijos e hijas del general. En la primera entrega, el rostro de Francisco Villa es un close up que muestra las arrugas de sus ojos y ocupa una buena parte del espacio; junto a esa imagen aparecen edificios emblemáticos y calles de Parral. En cuatro de siete entregas, aparece en alguna fotografía Regino Hernández acompañando a Villa. En la cuarta entrega, una imagen desproporcionadamente grande del hijo de Villa, un bebé sentado que observa hacia la cámara, se recorta en silueta por encima de unas fotografías panorámicas del alumnado infantil que asiste a la escuela "Felipe Ángeles", e incluso una fotografía de Villa a caballo es de menores dimensiones que la imagen del bebé.

Como resume Armando Bartra (1999, p. 40), "el fotorreportaje es, ante todo, puesta en página"; "los primeros relatos fotográficos de nuestro periodismo son documentales; crónicas de actualidad en las que cuenta la oportunidad y el valor intrínseco de cada toma". El periodismo llamativo y noticioso que ya se vislumbraba en los reportajes de cuatro décadas atrás, 
ha condicionado un formato, un encuadre y una composición que creó, para entonces, "un estilo específicamente periodístico de fotografiar” (p. 36). John Mraz (2010) llama la atención sobre esta particularidad a propósito de la famosa fotografía de Villa ocupando la silla presidencial. Las dos tomas que se conocen ampliamente delatan las distintas formaciones en el oficio. Mientras que en la imagen obtenida por Antonio Garduño, "muy en la línea estética de fotografía de estudio", los personajes posan "y la mayoría mira a la cámara; el general Tomás Urbina tiene sus ojos abiertos y Rodolfo Fierro encara al fotógrafo" (p. 234), en la otra imagen, la mayoría no mira a la cámara; Villa y Zapata conversan, Urbina tiene los ojos cerrados y Fierro observa a los líderes. Es una foto espontánea que "pertenece más al género del fotoperiodismo y fue sacada por el decano de los reporteros gráficos mexicanos, Manuel Ramos" (p. 235). La primera fue publicada en La Ilustración Semanaly ha sido recogida para libro y utilizada como base del mural de Arnold Belkin en el Museo Nacional de Historia. La de Ramos fue publicada en El Monitory, como ya se dijo, incorporada en Ocho mil kilómetros en campaña (pp. 234-235).

Como bien se sabe, la adjudicación autoral de las fotografías de temática revolucionaria ha sido un trabajo de muchas décadas debido a que el Archivo Casasola fue por mucho tiempo fuente fundamental, en la que Agustín Víctor borró los nombres de los fotógrafos en miles de negativos; además, no siempre los periódicos asentaron el nombre de sus fotógrafos, sino que colaboraron desde el anonimato (pp. 11-14). El conocimiento de la autoría, de la imagen completa y de la circunstancia de publicación de la icónica "Adelita", por ejemplo, es relativamente reciente, por lo que no podemos dejar de subrayar las modificaciones que sufrieron las imágenes presentadas en "Una semana con Francisco Villa en Canutillo" como parte de una edición visual con una carga determinante al mismo nivel del discurso verbal de Hernández Llergo. Además de ser el centro del reportaje, Villa es la imagen predominante en cada entrega, en distintas poses: montado a caballo, hablando con un labriego, cargando a su hijo, e incluso en dibujo levemente caricaturizado.

Lo anterior es de relevancia porque el texto confeccionado por Regino Hernández describe, desde el arranque, que el equipo que se traslada a Canutillo está compuesto por Regino, una amiga llamada Emilia y el fotógrafo Fernando Sosa, a quien 
presenta como "redactor gráfico de El Universal". Este último aparece reiteradamente aludido en Canutillo cumpliendo sus labores fotográficas. El collage visual de las siete entregas puede dar la impresión de abundancia de imágenes levantadas, pues ocupan mucho espacio en la plana, pero una escena narrada en el reportaje nos revela el control que Villa ejercía sobre las imágenes tomadas en su hacienda, y entonces, observando con atención, la mayor parte de las fotografías de personas se reconocen como poses.

La escena es la siguiente: "Cuando salimos de allí, mientras Fernando tomaba algunas fotografías de la hacienda, un poco lejos de nosotros, el general me llamó con mucho misterio, y recargándose en una pared, me interrogó" (14 de junio de 1922, p. 7). El general le pregunta qué impresión tenía de él antes de conocerlo. Es un momento angustioso para Regino pues le contesta que una buena impresión, y Villa lo mira fijamente, se ríe y le dice: "No, amigo, no me engañe. Yo sé que en México, Francisco Villa es un bandido. Para aquellos lugares, yo soy un hombre malo. Y no es cierto, amigo, yo sólo he luchado en defensa de mi raza, de mis hermanos". Vemos a Villa con una gran conciencia figurativa, negociando su imagen con el reportero desde el primer día de recorrido por su hacienda. "¿Yqué impresión tiene usted ahora de mí? Buena, ¿verdad? -se respondió él mismo" $(i d$.$) . Aunque el reportero le contesta que ve en$ él un hombre generoso por su manera de tratar a la gente de la hacienda, Villa recibe las palabras con un gesto de incredulidad. Debajo del título del reportaje, en el sumario o friso donde se acostumbra resumir los asuntos que tratará el texto, se prometía este fragmento como "Una conversación confidencial", aunque en el cuerpo del reportaje esté cabeceado como "¿Qué impresión tenía usted de mí?”. Ese ambiente de confidencialidad aludido debió de serlo si atendemos a la reacción de Villa frente al disparo de la cámara, al tomar la fotografía más famosa y reproducida del reportaje:

En ese momento, Fernando, que sólo esperaba oportunidades para trabajar, nos enfocó la cámara y tomó la fotografía que aparece en este capítulo.

El general, cariñosamente, pero con cierta energía, protestó, diciéndole al camarada fotógrafo:

-No me ande haciendo eso, amigo...

-No, general, no fue nada -alegó Fernando, palideciendo. 
Tres miembros de su escolta -a juzgar por la pistola que traían al cinto- aparecieron en escena, informando al general que la trilladora que se había descompuesto, estaba lista $(i d$.$) .$

El breve pero significativo diálogo -concluido, además, con la irrupción de su escolta armada- permite replantear el grado de intervención y control del entrevistado en el ejercicio figurativo del reportaje. Las escenas de charla son administradas por Villa, quien le había puesto como condición al reportero que no hablarían de política, pero, a decir de Hernández Llergo, "de lo que con mayor amplitud me habló el general Villa, fue de política y eso sin que yo iniciara la conversación, respetando su deseo sólo le hacía preguntas cuando él ya había entrado de lleno en el curso de la platicada" $(i d$.). Villa elige los sitios que recorrerá con los periodistas, y en cada uno de ellos señala el trabajo que ha invertido para su aprovechamiento, ponderación a la que une las virtudes de su persona. Los sitios son descritos con esos detalles y apreciaciones por el reportero e ilustrados muy al gusto del general, pues muestran y documentan la imagen que desea proyectar. Inclusive hay un momento en que indica al experto en qué colocación obtendría una mejor vista de los campos de trigo: "-¡A ver, joven fotógrafo, tómelo desde aquí mejor -ofreciéndole su lugar-, aquí se mira más grande! Y dirigiéndose a mí: -¡Para que vean en México que Francisco Villa es bueno para trabajar en beneficio de su raza!" (18 de junio de 1922, p. 1). La fotografía queda incluida en el reportaje con el pie de foto "Uno de los espléndidos campos de trigo de la Hacienda de Canutillo". Es la última entrega de un reportaje que asentó en las orejas del cintillo del título tanto el crédito de Regino Hernández Llergo como el de Fernando Sosa como fotógrafo.

Sosa había seguido los pasos de su hermano Rafael, reconocido fotógrafo de prensa. Su primer trabajo fue para La Semana Ilustrada en agosto de 1914; juntos acompañaron a Venustiano Carranza a Veracruz como encargados del periódico El Pueblo. De regreso a la capital trabajó para $E l$ Liberaly más tarde para $E l$ Heraldo de México. Se incorporó a El Universal a partir de 1921, y llegó a ser jefe del Departamento de Fotografía. Mostró especial interés por fotografiar el fusilamiento de los hermanos Humberto y Miguel Agustín Pro, Luis Segura Vilchis y Juan Antonio Tirado (Monroy 2007, p. 150), que apareció en las primeras planas de El Universal durante tres días de noviembre de 1927, lue- 
go del fallido atentado contra Álvaro Obregón. Cuando un año después ocurrió el magnicidio, en comandita con el reportero Óscar Leblanc [Arqueles Vela], Fernando Sosa cubrió visualmente el juicio de José de León Toral y la madre Concepción Acevedo de la Llata, a quienes tomó fotografías dentro de las celdas para conocer su estado físico y anímico, que el reportero literato recupera también con sorpresa que nos recuerda la de Villa en Canutillo, pues describe que "en el momento en que Sosa disparó su cámara, se «ilumina la estancia con su flash de magnesio y de las bartolinas de la prisión sale un grito ahogado de angustia»" (Leblanc, apud Monroy 2003, p. 126).

Como intenté mostrar, el acompañamiento visual es mucho más que eso en la conformación discursiva de "Una semana con Francisco Villa en Canutillo". De ida y vuelta, los textos verbal y visual; ninguno de ellos rinde por completo su significado hasta que se entrelaza con el otro. Los espacios y los personajes retratados cobran sentido completo al momento de la lectura, donde se demuestra cómo la función primaria que cumplen las fotografías son las de ilustrar y hacer más ameno el relato; no obstante, debemos a la prolijidad visual la eficiencia de la narración, que sólo se detiene para crear ambientes o revelar rasgos anímicos de los personajes.

$\mathrm{Si}$ en un reportaje publicado hace no muchos años, fue muy comentada la ausencia de biblioteca en la casa del presidente, vacío que pareció confirmar la percepción generalizada de su escasa cultura, la presencia de una fotografía con la modesta pero variada selección bibliográfica detallada por el reportero es uno más de esos múltiples elementos significativos a los que Villa atendió en la construcción de la imagen que quiso mostrar a los lectores de un periódico de circulación nacional, incluso en el detalle ridículo de aclarar que El cocinero moderno era un libro de Betita, no de él. Llama la atención, por cierto, la presencia de anuncios comerciales en la parte inferior de la plana -lo cual pertenece a la dimensión comercial del medio en que apareció el reportaje, asunto al que aquí no se ha atendido-, entre los cuales figuran El tesoro de la juventud -que será mencionado al día siguiente como parte de la biblioteca de Villa-y las pistolas Savage-la misma con que Obregón disparó sin éxito sobre su sien izquierda-, aparte de muchos otros productos.

Espacio escritural que resguarda y autentifica las palabras dichas, la entrevista, desde finales del siglo xIx, resultó un "medio inestimable para el conocimiento de personas, perso- 
nalidades e historias de vidas ilustres y comunes". Además de ser "menos fantasiosa que la biografía" y estar "anclada a la palabra dicha", mostró en la proximidad "su poder de brindar un retrato fiel -en tanto atestiguado por la voz-y al mismo tiempo no concluido..., sino ofrecido a la deriva de la interacción, a la intuición, a la astucia semiótica de la mirada, de lo sugerido en el aspecto, el gesto, la fisonomía, el ámbito físico, escenográfico, del encuentro" (Arfuch 2002, pp. 117-118). En esa construcción a trío -Regino, Sosa, Villa-, Villa intervino de una manera directa, confiando siempre a la oralidad propia de la entrevista la narración o interpretación de sucesos del pasado; otras veces, posando cuidadosamente las mil facetas de Francisco Villa hacendado, antiguo combatiente que se mantenía silencito, benefactor de su comunidad, padre de familia y mexicano preocupado por su raza.

En otro lugar (Viveros 2017, pp. 319-340) me he detenido en las consecuencias de la empedernida oralidad a la que recurrió Villa por razones evidentes, que hacen de los cuadernos taquigráficos de Manuel Bauche Alcalde (1914) y del libro de Ramón Puente, publicado desde el exilio, Vida de Francisco Villa contada por él mismo (1919) -y sus avatares editoriales con añadidos de Rafael F. Muñoz-, algunos de los cuestionables pero imprescindibles insumos para todo aquel que desea pergeñar una biografía del caudillo. Tal vez por ello, la escritura sobre Villa, "publicada entre 1916 y 1936, se alimentó del testimonio, de la leyenda, de la canción popular, de los datos históricos y de la imaginación" (Tapia 2019, p. 75). Si como señala Jazmín Tapia, "la situación de testigo es fundamental para Puente, Bauche y Guzmán, quienes la ponderan como una forma de dar «su palabra» al lector de que lo narrado es verídico o, en el caso del autor chihuahuense, funciona como una estrategia de verosimilitud", en todas ellas la función del testigo "opera como un vehículo de transmisión de la memoria, pero no sólo la del general, sino la del propio testigo, quien recupera su memoria en el presente de la escritura al recordar cómo fueron transmitidos a su vez los recuerdos de Francisco Villa” (pp. 95-96).

Esta presencia del mediador resulta muy evidente en la figuración de Villa en "Una semana con Villa en Canutillo" y, sin embargo, está también presente, de otra forma, en la fuerza documental de las fotografías de Jesús H. Abitia, que acompañan Ocho mil kilómetros en campaña, reconocido por Obregón como quien "con mucho arrojo y en circunstancias verdadera- 
mente peligrosas, se dedicaba a tomar vistas cinematográficas de los combates" (1917, p. 585). El acompañamiento de fotógrafos y camarógrafos implicaba un gasto enorme y una serie de complicaciones materiales (películas, químicos, cámaras, tripiés, asistentes y equipo) que hace necesaria la pregunta por quién los costea y para qué fines (Mraz 2010, p. 13). Para 1916, Abitia había grabado "cerca de sesenta mil pies de película" (p. 186) y "contaba con un furgón de cola de tren para llevar su equipo" (p. 187); era "una pieza de la maquinaria propagandística constitucionalista” (p. 189), por su inmensa labor. Esa impronta debe advertirse en la integración de sus imágenes en el discurso de Obregón.

Hoy los textos pertenecientes al espacio autobiográfico se están revalorando como fuentes de hechos y percepciones no considerados, soslayados u obscurecidos por la historiografía inmediata, que permite reconstruir un escenario visto desde la mirada de los protagonistas, si bien es necesario no olvidar que la memoración ocurre siempre desde un punto distinto a la del acontecimiento. El tiempo ha ejercido en la operación memorialística una distancia, con las variadas consecuencias que esto conlleva. Como señala Ricoeur (2003, pp. 208-214), la confrontación de testimonios no ofrece necesariamente una verdad, sino acaso una explicación tanto del episodio a dilucidar como de la importancia misma del episodio como punto crítico: traumático o fundacional.

Francisco L. Urquizo, al mirar retrospectivamente hacia los años revolucionarios desde sus casi siete décadas de vida, afirma:

Nuestra mente almacena constantemente recuerdos; es un archivo interminable desde que se tiene uso de razón hasta que se pierden los sentidos en los aledaños de la muerte. Pero de ese archivo inmenso que reunimos en las células del cerebro, hay recuerdos que tienen más firmeza y que se imponen a los otros, a los de todos los días y son aquellos que se grabaron más por las circunstancias en que los vivimos, por la huella que nos dejaron o por la trascendencia de lo que ocurrió (1960, pp. xvii-xviii).

La necesidad de construir discursivamente la propia participación en un hecho trascendente -y el punto más alto de esta ambición, ser el personaje trascendente, como vimos con Obregón y con Villa- pudo ser uno de los motores del auge autobiográfico sobre la Revolución Mexicana. 


\section{REFERENCIAS}

Abitia Garcés, Jesús H. 1959. "Memorias de un fotógrafo constitucionalista”, El Universal, "Revista de la Semana”, 22 de febrero, p. 1.

Arfuch, LeOnor 2002. El espacio biográfico. Dilemas de la subjetividad contemporánea, Fondo de Cultura Económica, Buenos Aires.

AristizÁbal, Catherine 2012. Autodocumentos hispanoamericanos del siglo XIX. Fuentes personales y análisis histórico, Lit Verlag, Berlin.

BARtra, Armando 1999. "La narrativa fotográfica en la prensa mexicana", Luna Córnea, 18, pp. 30-52.

Bonilla, LAURA Edith 2002. Ángel Pola: una interpretación decimonónica de la realidad a través del periodismo, Universidad Nacional Autónoma de México, México.

Bonilla, Laura Edith 2014. Manuel Caballero. Historia y periodismo en la conformación de una modernidad porfiriana. Universidad Nacional Autónoma de México, México.

Castillo Troncoso, Alberto del 2007. "La frontera imaginaria. Usos y manipulaciones de la fotografía en la investigación histórica en México", Cuicuilco, 14, 41, pp. 193-215.

Chartier, Roger 2015. La obra, el taller y el escenario. Tres estudios de movilidad textual. Trad. José Miguel Parra, Centro para la Edición de los Estudios Clásicos-Editorial Confluencias, Salamanca. (Colección L'Hexagone, 11).

Cosío Villegas, Daniel 2004 [1949]. "El Porfiriato: su historiografía o arte histórico”, en Extremos de América, Fondo de Cultura Económica, México, pp. 105-154.

Gamboa, Federico 1996. Mi diario VII. (1920-1939). Mucho de mi vida y algo de la de otros, Consejo Nacional para la Cultura y las Artes, México.

Garciadiego, Javier 2004. "Estudio introductorio", en Álvaro Obregón, La Revolución Mexicana. Crónicas, documentos, planes y testimonios, Universidad Nacional Autónoma de México, México, pp. xiii-xcii. (Biblioteca del Estudiante Universitario, 138).

Garciadiego, Javier 2007. "José C. Valadés y la historiografía de los vencidos”, en José C. Valadés, La Revolución y los revolucionarios. T. 3: La Revolución constitucionalista, Instituto Nacional de Estudios Históricos de las Revoluciones de México, México, pp. 9-20.

Gómez, Elizabeth (investigación en curso). "Prensa y representaciones discursivas autobiográficas en el siglo xx".

Hernández Llergo, Regino 1922. "Una semana con Francisco Villa en Canutillo", El Universal, 2a sección, 12 al 18 de junio, año 7, t. 23, núms. 2063, pp. 1, 7; 2064, pp. 1, 7; 2065, pp. 1, 7; 2066, pp. 1, 7; 2067, pp. 1, 7; 2068, pp. 1, 7; 2069, pp. 1, 3.

Katz, Friedrich 1998. Pancho Villa, t. 2. Trad. Paloma Villegas, Era, México.

Lejeune, Philippe 1994. El pacto autobiográfico y otros estudios. Trad. Ana Torrent, Megazul-Endymion, Madrid.

Maytorena, José M. 1919. Algunas verdades sobre el general Álvaro Obregón, Imprenta del Heraldo de México, Los Ángeles, CA.

Mitchell, W.J.T. 2009. "El ensayo fotográfico: cuatro casos de estudio", en Teoría de la imagen, Akal, Madrid, pp. 245-279. 
Molloy, Sylvia 1996. Acto de presencia. La escritura autobiográfica en Hispanoamérica. Trad. José Esteban Calderón, El Colegio de México-Fondo de Cultura Económica, México.

Monroy Nasr, Rebeca 2003. Historias para ver: Enrique Díaz, fotorreportero, Universidad Nacional Autónoma de México-Consejo Nacional para la Cultura y las Artes-Instituto Nacional de Antropología e Historia, México. (Estudios de Fotografía, 2).

Monroy Nasr, Rebeca 2007. "Haz de luz: la mirada de Antonio Rodríguez y el fotoperiodismo contemporáneo", Cuicuilco, 14, 41, pp. 143-167.

Mraz, John 2010. Fotografiar la Revolución Mexicana. Compromisos e iconos, Instituto Nacional de Antropología e Historia, México.

Obregón, Álvaro 1917. Ocho mil kilómetros en campaña. Relación de las acciones de armas, efectuadas en más de veinte estados de la República durante un periodo de cuatro años por el C. General Álvaro Obregón y descritas por él mismo, Librería de la Vda. de Ch. Bouret, México.

Obregón, Álvaro 1960. Ocho mil kilómetros en campaña, $3^{\mathrm{a}}$ ed. Estudios preliminares de Francisco L. Urquizo y Francisco J. Grajales. Apéndice de Manuel González Ramírez, Fondo de Cultura Económica, México.

Olea Franco, Rafael 2012. "La Novela de la Revolución Mexicana: una propuesta de relectura”, Nueva Revista de Filología Hispánica, 60, 2, pp. 479-514; doi: 10.24201/nrfh.v60i2.1057.

Pacheco, José Emilio 1959. "Obregón en campaña”, México en la Cultura, 545, 23 de agosto, pp. 4-10.

Pani, Erika 2004. El Segundo Imperio. Pasados de usos múltiples, Centro de Investigación y Docencia Económicas-Fondo de Cultura Económica, México.

Pi-Suñer Llorens, Antonia 2011. "Introducción", en Historiografía Mexicana. T. 4: En busca de un discurso integrador de la nación, 1848-1884, $2^{\mathrm{a}}$ reimpr. Eds. Juan A. Ortega y Medina, Rosa Camelo y Antonia Pi-Suñer, Universidad Nacional Autónoma de México, México, pp. 9-30.

Pola, Ángel 1887. "15 de mayo de 1867”, El Diario del Hogar, 6, 206, 15 de mayo, pp. 1-2.

Ricoeur, Paul 2003. La memoria, la historia y el olvido. Trad. Agustín Neira, Trotta, Madrid.

Salmerón Sanginés, Pedro 2009. "Los historiadores y la guerra civil de 1915. Origen y persistencia de un canon historiográfico", Historia Mexicana, 58, 4, pp. 1305-1368.

SÁnchez Azcona, JuAn 1930. "Mis contemporáneos. Notas sintéticas y anecdóticas”, La Prensa [San Antonio, Texas], 18, 141, 3 de julio, p. 3.

Sierra García, Antonio y Carlos Ramírez Vuelvas 2009. "Un doble discurso compartido", en Regino Hernández Llergo, Una semana con Villa en Canutillo. Ed. y est. prel. de Antonio Sierra García y Carlos Ramírez Vuelvas, Universidad de Colima, Colima, pp. 9-62.

Tapia Vázquez, Jazmín Guadalupe 2019. Memorias de Pancho Villa, de Martín Luis Guzmán: una estética de la integración, tesis, El Colegio de México, México.

Urquizo, Francisco L. 1960. “Obregón, militar”, en Álvaro Obregón, Ocho mil kilómetros en campaña, $3^{\text {a }}$ ed. Estudios preliminares de F.L. Urquizo y 
F.J. Grajales. Apéndice de M. González Ramírez, Fondo de Cultura Económica, México, pp. xvii-xxxi.

Viveros Anaya, Luz América 2017. "La narrativa testimonial en los años de publicación de Los de abajo (1915-1925)", en Mariano Azuela y la literatura de la Revolución Mexicana. Ed. Rafael Olea Franco, El Colegio de México, México, pp. 319-340.

Viveros Anaya, Luz América 2019. "Recuerdos de juventud de un lagartijo de antaño", en José M. Hidalgo y Esnaurrízar, Recuerdos de juventud. Memorias intimas de don José Hidalgo, antiguo ministro de México en diversas cortes de Europa (1887). Ed. crít. de L.A. Viveros Anaya, Universidad Nacional Autónoma de México, México, pp. xxxix-xciii. 
